\title{
Peripheral Arteriovenous Malformations: Imaging and Endovascular Management Strategies
}

\author{
Virender Malik ${ }^{1, \odot ~ H a r s h i t h ~ K r a m a d h a r i ² ~ J a w a h a r ~ R a t h o d ~}{ }^{3} \quad$ Yadav W. Munde $^{4, \odot ~ U d a y ~ B h a n u ~ K o v i l a p u ~}{ }^{5}$
}

${ }^{1}$ Army Institute of Cardiothoracic sciences (AICTS), affiliated to

Armed Forces Medical College, Pune, India

${ }^{2}$ KS Hegde Medical Academy, Derlakatte, Mangalore, India

${ }^{3}$ Government Medical College and Hospital, Nagpur, India

${ }^{4}$ Ruby Hall Clinic, Pune, India

${ }^{5}$ Armed Forces Medical College, India

J Clin Interv Radiol ISVIR 2021;6:43-51.

\author{
Address for correspondence Yadav W. Munde, MD (Rad), Chief \\ Interventional Radiologist, Department of Interventional Radiology, \\ 6th Floor, Cancer Centre, Ruby Hall Clinic, Sasoon Road, \\ Pune 411001, India (e-mail: yadavmunde@gmail.com).
}

\begin{abstract}
Keywords

- peripheral arteriovenous malformations

- endovascular management strategies

The peripheral high-flow vascular malformation (HFVM) comprises arteriovenous malformation (AVM) and fistula (AVF), shows varied clinical presentation (ranging from subtle skin lesion to life-threatening congestive heart failure), and frequently poses diagnostic and therapeutic challenges. Importance of assigning a specific diagnosis to the vascular malformation cannot be overstated, as the treatment strategy is based on the type of vascular anomaly. Although the International Society for the Study of Vascular Anomalies (ISSVA) classification system is the most commonly accepted system for classifying congenital vascular anomalies in clinical practice, the Cho-Do et al classification is of utmost help in guiding optimal mode of treatment in peripheral AVM. Although transarterial approach remains the most commonly employed route for peripheral AVM embolization, the role of transvenous and direct percutaneous approach is ever increasing and the final decision on the approach depends on angioarchitecture of the AVM. In this article, we review various commonly employed classification systems for congenital vascular anomalies, and describe clinical features, imaging and treatment strategies for peripheral arteriovenous malformation (PAVM).
\end{abstract}

\section{Introduction}

The peripheral high-flow vascular malformation (HFVM) comprises arteriovenous malformation (AVM) and fistula (AVF), shows varied clinical presentation (ranging from subtle skin lesion to life-threatening congestive heart failure), and frequently poses diagnostic and therapeutic challenges. The importance of assigning a specific diagnosis to the vascular malformation cannot be overstated, as the treatment strategy is based on the type of vascular anomaly. In this article, we review various commonly employed classification systems for congenital vascular anomalies, and describe

published online May 18, 2021
DOI https://doi.org/

$10.1055 / \mathrm{s}-0041-1728986$ ISSN 2457-0214 clinical features, imaging and treatment strategies for peripheral arteriovenous malformation (PAVM).

\section{Classification Systems for Congenital Vascular Anomalies}

Various classification systems have been in use with the aim of providing standard universal terminology, making accurate diagnosis and thereby optimizing treatment strategy. ${ }^{1,2}$

The widely accepted classification, proposed by Mulliken and Glowacki in 1982, is a biological classification, based on the histologic features, natural history and physical findings. ${ }^{3}$ This classification assigns particular nomenclature to
(C) 2021. Indian Society of Vascular and Interventional Radiology. This is an open access article published by Thieme under the terms of the Creative Commons Attribution-NonDerivative-NonCommercial-License, permitting copying and reproduction so long as the original work is given appropriate credit. Contents may not be used for commercial purposes, or adapted, remixed, transformed or built upon. (https://creativecommons.org/licenses/by-nc-nd/4.0/). Thieme Medical and Scientific Publishers Pvt. Ltd. A-12, 2nd Floor, Sector 2, Noida-201301 UP, India 
the vascular anomalies, based on the preponderant vascular channel (capillary, venous lymphatic, arterial, or combined) and differentiates hemangioma from vascular malformation, based on the degree of cellular turnover and presence or absence of dysplastic vascular channels. Subsequently, in 1993 Jackson et al proposed a classification, based on the parameter of flow dynamics, classifying vascular anomalies as low-flow or high-flow malformations. ${ }^{4}$ The International Society for the Study of Vascular Anomalies (ISSVA), in 1996, adopted and expanded these systems, considering vascular tumors and vascular malformations as two different broad categories; further, it subcategorized the latter as low- and high-flow malformations, based on the flow dynamics. ${ }^{5}$ The presence or absence of arterial component classifies lesions as high- and low-flow malformations, respectively, with endovascular being the preferred route of treatment in the former, while direct sclerotherapy for the latter group.

The 2014 ISSVA Classification of Vascular anomalies incorporated recent advances in the genetic and pathologic characteristics of these diseases and grouped lesions as simple, combined and truncular vascular malformations along with manifestation of these malformations as part of a syndrome (-Table 1). ${ }^{6}$ The simple and combined vascular malformations are characterized by involvement of only one type of vessel or a combination of various vessel types, respectively.

Cho-Do et $\mathrm{al}^{7}$ and Yakes ${ }^{8}$ recently introduced classification systems for AVM, based on morphology of AVM and is helpful in guiding optimal mode of treatment.

\section{Clinical Presentation}

HFVM comprises AVM and AVF, with the most common presentation noted in the late childhood as a red, pulsatile, warm mass with a thrill and grows proportionally with the child without regression. The AVMs characteristically

Table 12014 ISSVA classification of vascular anomalies

\begin{tabular}{|l|l|}
\hline \multicolumn{2}{|l|}{ Vascular tumors } \\
\hline \multicolumn{2}{|l|}{ Benign, borderline, malignant } \\
\hline \multicolumn{2}{|l|}{ Vascular malformations $^{\text {Capillary, venous, lymphatic, AVM }{ }^{\text {b }} \text {, AVF }}{ }^{\text {b }}$} \\
\hline Simple $^{\text {a }}$ & $\begin{array}{l}\text { Any combination of simple malformations } \\
\text { (e.g., capillary-venous, venous-lymphatic, } \\
\text { capillary-lymphatic-venous) }\end{array}$ \\
\hline Truncular $^{\text {c }}$ & $\begin{array}{l}\text { Vessel involved (artery, vein or lymphatic) } \\
\text { Anomaly of: origin, course, number, length, } \\
\text { diameter, valves, communication, persistence } \\
\text { (embryonal) }\end{array}$ \\
\hline $\begin{array}{l}\text { Malformation } \\
\text { part of clinical } \\
\text { syndrome }\end{array}$ & $\begin{array}{l}\text { Klippel-Trenaunay, Parkes-Weber, Sturge- } \\
\text { Weber, Mafucci, Proteus syndrome }\end{array}$ \\
\hline
\end{tabular}

Abbreviations: AVFs, arteriovenous fistulas; AVMs, arteriovenous malformations; ISSVA, International Society for the Study of Vascular Anomalies.

${ }^{a}$ Consist of a single type of vascular channel and named according to the vessel type involved. * single malformations composed of several vessel types, as opposed to a combination of multiple malformations, so included in simple vascular malformations group. ' two or more distinct vascular malformations within a single lesion. ${ }^{\mathrm{d}}$ malformations of major named vessels. comprise feeding arteries, nidus, and draining veins ( - Fig. $\mathbf{1}$ ). The AVFs are characterized by a single vascular channel between an artery and a vein. ${ }^{9-11}$ The AVMs, although present at birth, usually manifest later, as the lesion increases proportionate to child growth, with exacerbations noted consequent to hormonal changes (puberty or pregnancy), infection, thrombosis, or trauma. ${ }^{9,11,12}$ The presentation may be varied, ranging from asymptomatic or minimal dermatologic features (cutaneous blush or warmth) to high-output cardiac failure. ${ }^{12-14}$ The Schobinger staging system is a four-stage AVM classification, based on clinical manifestations of an AVM, ranging from minor dermatologic findings in stage I to high-output cardiac failure in stage IV. ${ }^{14}$

The proliferating phase of infantile hemangiomas is also a high-flow lesion but categorized as a vascular tumor (not malformation) which shows regression over time, unlike vascular malformations. Whereas presence of limb length or size discrepancy suggests Parkes-Weber syndrome, the macrocephalia and hamartoma are indicators of Cowden syndromes. The presence of multiple intramuscular AVMs, ectopic fat overgrowth, and intracranial developmental anomalies are some of the pointers to a syndromic association in peripheral AVM.

\section{Imaging Modalities}

Although the plain radiographs play a limited role in classifying the vascular malformations, the presence of phleboliths strongly suggest diagnosis of venous malformations or hemangioma. ${ }^{15}$ Gray-scale ultrasound (US) and Doppler are usually the initial imaging modalities undertaken, providing a differentiation not only between hemangiomas and vascular malformations, but also a more important treatment guiding distinction between low and high flow vascular malformations. ${ }^{9,16,17}$ Presence of arterial spectral waveform, turbulent multidirectional flow of blood, spectral broadening and shunts indicate a HFVM. Posttreatment Doppler study by assessing the arterial flow can determine the success of the

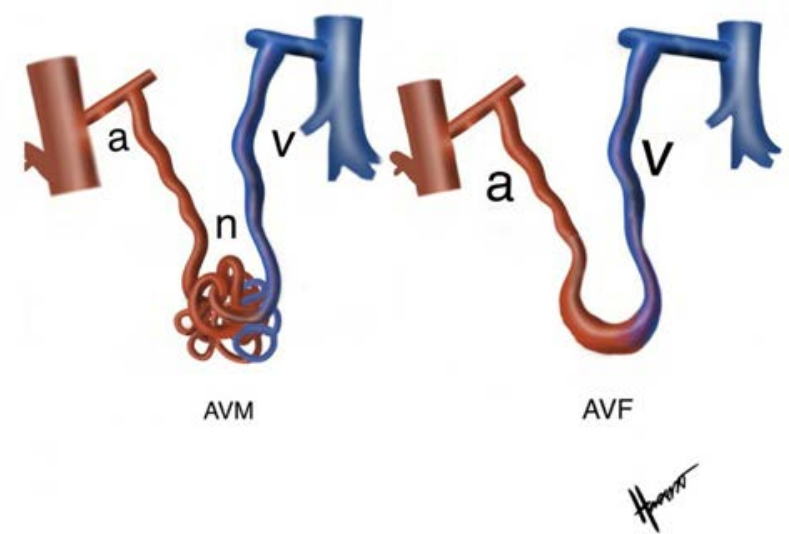

Fig. 1 Diagrammatic representation depicting an arteriovenous malformation (AVM) with an arterial feeder (a), early draining vein $(v)$ and an intervening abnormal tangle of vessels; nidus ( $n$ ). Arteriovenous fistula (AVF) is characterized by a feeding artery (a) and a draining vein ( $v$ ) with no intervening nidus. Arrows indicate the direction of flow. 
procedure. ${ }^{18}$ The limited field of view, suboptimal evaluation of deeper placed lesions, and operator dependency are few of the limitations with this technique. ${ }^{19}$

MRI is the most valuable imaging modality aiding in accurate classification of vascular anomalies. ${ }^{20}$ By defining the extent of lesion, its anatomic relationship to important adjacent structures, providing differentiation between low and high-flow malformations, and allowing detailed assessment of angioarchitecture, MR imaging helps not only in accurate diagnosis but also plays an important role in treatment planning. ${ }^{21}$

The sequences with specific information provided by each is summarized in - Table 2 .

Table 2 MR sequences for detailed evaluation of vascular malformations

\begin{tabular}{|c|c|c|}
\hline $\begin{array}{l}\text { MRI } \\
\text { Sequence }\end{array}$ & $\begin{array}{l}\text { Specific } \\
\text { information } \\
\text { obtained }\end{array}$ & Remarks \\
\hline $\begin{array}{l}\text { SE or fast SE } \\
\text { T1-W }\end{array}$ & $\begin{array}{l}\text { Basic anatomic } \\
\text { evaluation }\end{array}$ & \\
\hline $\begin{array}{l}\text { FS fast SE } \\
\text { T2-W or STIR }\end{array}$ & $\begin{array}{l}\text { Assess lesion } \\
\text { extension }\end{array}$ & $\begin{array}{l}\text { Exquisitely define the } \\
\text { extent of vascular } \\
\text { malformations }\end{array}$ \\
\hline GRE T2 *-W & $\begin{array}{l}\text { Calcification or } \\
\text { hemosiderin }\end{array}$ & $\begin{array}{l}\text { Calcification or hemo- } \\
\text { siderin appear as intense } \\
\text { focal hypointensities } \\
\text { Signal in blood vessel on } \\
\text { GRE sequence: } \\
\text { - Absent (low-flow } \\
\text { malformation) } \\
\text { - High (high-flow } \\
\text { malformation) }\end{array}$ \\
\hline $\begin{array}{l}\text { 3D T1-W fast } \\
\text { GRE CE MRA }\end{array}$ & $\begin{array}{l}\text { Angioarchitecture } \\
\text { assessment }\end{array}$ & $\begin{array}{l}\text { Evaluate perfusion of the } \\
\text { lesion } \\
\text { Imaging performed in } \\
\text { arterial and multiple } \\
\text { venous phases (early, } \\
\text { intermediate, and late) } \\
\text { with } 30 \text { sec delay between } \\
\text { each. }\end{array}$ \\
\hline $\begin{array}{l}\text { Dynamic } \\
\text { time-re- } \\
\text { solved MR } \\
\text { angiography }\end{array}$ & $\begin{array}{l}\text { Excellent depic- } \\
\text { tion of angioar- } \\
\text { chitecture and } \\
\text { assessment of } \\
\text { hemodynamic } \\
\text { properties } \\
\text { of vascular } \\
\text { malformations }\end{array}$ & $\begin{array}{l}\text { Involves creative acquisi- } \\
\text { tion of k-space } \\
\text { Multiple data sets acquisi- } \\
\text { tion (one 3D dataset every } \\
2 \text { seconds) high temporal } \\
\text { and spatial resolution per- } \\
\text { mits separation of arterial } \\
\text { inflow from venous drain- } \\
\text { age, detection of early } \\
\text { venous shunting, and } \\
\text { contrast material arrival } \\
\text { time information }\end{array}$ \\
\hline $\begin{array}{l}\text { Unenhanced } \\
\text { and delayed } \\
\text { contrast } \\
\text { enhanced FS } \\
\text { 3D T1-W GRE } \\
\text { (delay of 5-10 } \\
\text { minutes) }\end{array}$ & $\begin{array}{l}\text { Provides high } \\
\text { spatial resolution } \\
\text { images of both } \\
\text { the vascular } \\
\text { system and the } \\
\text { surrounding soft } \\
\text { tissues }\end{array}$ & $\begin{array}{l}\text { Uses reduced flip angle } \\
\text { Provides nearly isotropic } \\
\text { resolution } \\
\text { Depicts the drainage } \\
\text { of malformation in the } \\
\text { venous system, help to } \\
\text { evaluate very-low-flow } \\
\text { malformations. }\end{array}$ \\
\hline
\end{tabular}

Abbreviations: CE MRA, contrast-enhanced magnetic resonance angiography; FS, fat-suppressed; GRE, gradient echo; STIR, short Tau inversion recovery; T1W, T1-weighted; T2-W, T2-weighted.
The presence of a well-defined lobulated masses showing high signal intensity (SI) on T2-W, intermediate SI on T1-W, flow voids on $\mathrm{T} 2-\mathrm{W}$, early intense and uniform enhancement with absence of arteriovenous shunting and perilesional edema are characteristic features of proliferative phase of hemangiomas. ${ }^{19,22}$ The presence of enlarged feeding arteries and draining veins, visualized as large flow voids (SE images) or high SI areas (gradient echo [GRE] images) with no definite mass lesion, are useful findings to classify the lesion as a HFVM. Dynamic time-resolved MR angiography, by providing information about hemodynamic properties of vascular malformations, excellent depiction of angioarchitecture, separation of arterial inflow from venous drainage, and detection of early venous shunting allow accurate classification of HFVM as either proliferative phase of hemangioma, AVM, or AVF. The AVM with intraosseous extension appears as decreased SI of marrow on T1-W images. ${ }^{12}$ Differentiating long-standing secondary AVFs from AVMs can be challenging, as the more proximal feeding arteries and distal draining veins enlarge over time in the former.

The AVM is visualized as a high-density area on plain CT with the nidus depiction and evidence of shunting appreciated on CT angiography (CTA). Despite higher temporal resolution and less procedural time of CTA compared to conventional magnetic resonance angiography (MRA), MRI is the preferred modality due to better soft-tissue characterization and absence of ionizing radiation risk. ${ }^{23}$

The catheter angiography remains the gold standard to evaluate the flow dynamics and angioarchitecture of the nidus, effectively aiding in optimization of treatment approach. ${ }^{23}$ Although angiography is generally undertaken for well worked-up patients with documented definitive indication for radiological intervention, its usage as primary diagnostic confirmatory imaging tool in atypical cases is not uncommon.

\section{Treatment of High-flow Vascular Malformations (HFVM)}

The importance of differentiation between low-flow vascular malformation (LFVM) and HFVM cannot be overstated as the usual treatment of choice for former is percutaneous sclerotherapy, whereas the endovascular approach is needed for the latter., ${ }^{9,1921,24}$ Identifying the lesion as LFVM is more important than determining the specific type of vascular channel it contains, as the treatment for both venous and lymphatic malformation is nearly identical (direct percutaneous sclerotherapy)..$^{11,13,25,26}$

The classical Schobinger stage I lesion is clinically quiescent and is usually managed with observation and close follow-up. Considering the symptomatology and weighing risk-benefit ratio, treatment could be undertaken and individualized for stage II patients. Early treatment is considered necessary for HFVM with presence of hemorrhage, high-output cardiac failure, chronic venous hypertension, disabling pain, functional disability, or cosmetic deformities. ${ }^{13,14}$ Liu et al observed progressive increase in Schobinger stage of AVM, with most worsening clinically before 
adulthood, emphasizing importance of an early definite treatment. ${ }^{27}$ The high morbidity and recurrence rate associated with surgical procedures, ever improving interventional hardware (permitting superselective techniques), and liquid embolic agents (- Table 3 ) have led to acceptance of endovascular techniques as the preferred mode of management of the peripheral AVM and AVF.,28

Whatever may be the approach chosen, complete obliteration of the nidus, hence arteriovenous shunting, remains the primary goal of endovascular treatment of AVMs. Although percutaneous approach to nidus is commonly undertaken in $\mathrm{AVM}$, its usage is predominantly supplementary, with endovascular route being the primary mode of embolization. ${ }^{19}$

-Fig. 2 and - Table 4 illustrates the key characteristics of the Cho-Do et al classification, emphasizing its influence on selecting an appropriate mode of endovascular management (-Fig. 3 and - Table 4).

Although transarterial approach is the most commonly employed route for AVM embolization, the final decision on the approach depends on angioarchitecture of the AVM. Type I AVMs have three or fewer feeding arteries shunting into a single draining vein. AVM with such morphology can be treated using either a transarterial or transvenous approach. Type II AVMs demonstrate arteriolovenous nidus structure, wherein multiple arterioles shunt blood into a single draining vein. As the vein in this type is usually much larger than the feeding arteries, transvenous approach becomes the preferred route in type 2 AVM. ${ }^{33}$ Type IIIa and IIIb both show

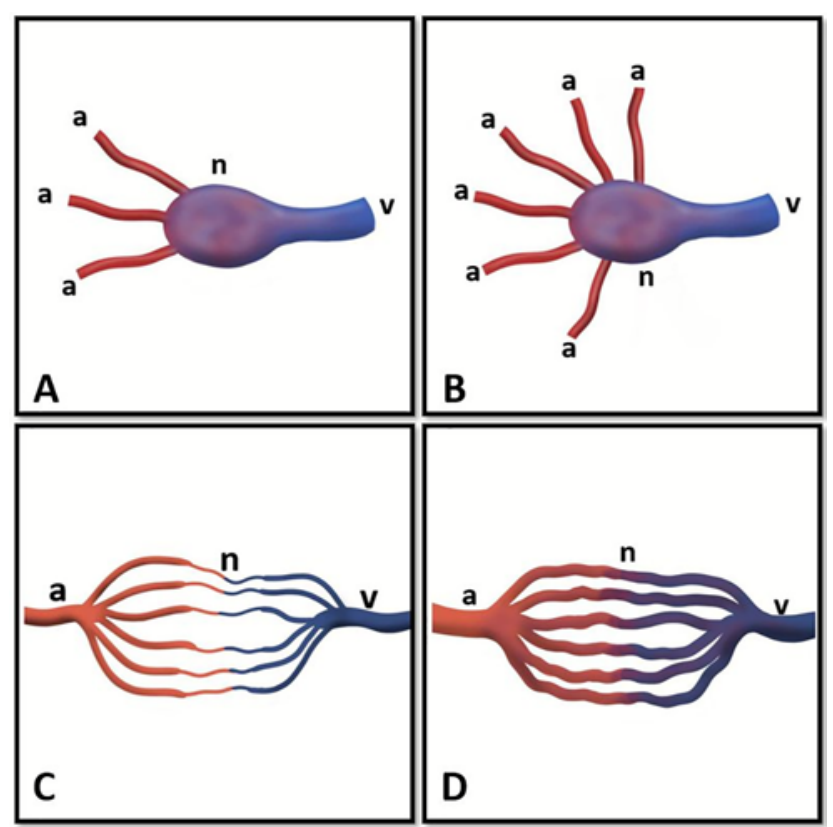

Fig. 2 (A-D) Cho-Do et al classification"7 diagrammatic representation. (A) Type I arteriovenous malformations (AVMs) has up to three arterial feeders with a single early draining vein. (B) Type II AVMs is characterized by multiple (> 3) arterial feeders draining into a single dilated outflow vein. (C) Type Illa AVMs shows multiple arterial feeders and draining veins, with no dilatation of intervening shunt vessels. (D) Type IIIb AVMs demonstrate appearances as in type IIIa lesion but with dilatation of shunt vessels. a: arterial feeder; v: draining vein; $n$ : nidus (shunt vessels). This figure has been adapted from Cho SK et $\mathrm{al}^{7}$ and modified by the author.
Table 3 Key characteristics of liquid embolic agents used in patients with AVMs and AVFs

\begin{tabular}{|c|c|c|}
\hline Embolic agent & Onyx & $\mathrm{n}-\mathrm{BCA}$ \\
\hline $\begin{array}{l}\text { Chemical } \\
\text { composition }\end{array}$ & $\mathrm{EVOH}^{29}$ & $\mathrm{n}-\mathrm{BCA}$ \\
\hline Priming agent & $\begin{array}{l}\text { DMSO (catheter } \\
\text { primed with DMSO) }\end{array}$ & $\begin{array}{l}\text { Dextrose (cathe- } \\
\text { ter primed with } \\
\text { Dextrose) }\end{array}$ \\
\hline $\begin{array}{l}\text { Visibility during } \\
\text { embolization }\end{array}$ & $\begin{array}{l}\text { Micronized tan- } \\
\text { talum provides } \\
\text { radio-opacity }\end{array}$ & $\begin{array}{l}\text { Lipidol provides } \\
\text { radio-opacity and } \\
\text { desired polymeriza } \\
\text { tion time }\end{array}$ \\
\hline Mechanism & $\begin{array}{l}\text { Precipitation, } \\
\text { nondhesive }^{30}\end{array}$ & $\begin{array}{l}\text { Fast polymerization } \\
\text { (on exposure to } \\
\text { the ionic environ- } \\
\text { ment of the blood, } \\
\text { Adhesive }^{31}\end{array}$ \\
\hline Catheter make & $\begin{array}{l}\text { Requires DMSO com- } \\
\text { patible catheters }^{31}\end{array}$ & $\begin{array}{l}\text { No catheter com- } \\
\text { patibility issues }\end{array}$ \\
\hline Preparation time & $\begin{array}{l}\text { Longer (shaken for } \\
\text { at least } 20 \text { minutes } \\
\text { in a mixer to obtain } \\
\text { a homogenous solu- } \\
\text { tion with tantalum } \\
\text { powder) }\end{array}$ & Short \\
\hline $\begin{array}{l}\text { Nontarget embo- } \\
\text { lization risk }\end{array}$ & $\begin{array}{l}\text { Lesser (allows } \\
\text { controlled } \\
\text { administration) }\end{array}$ & Relatively more \\
\hline $\begin{array}{l}\text { "Catheter stuck" } \\
\text { risk }\end{array}$ & Lesser & More \\
\hline Cost & More & Lesser \\
\hline $\begin{array}{l}\text { Postembolization } \\
\text { infection risk }\end{array}$ & Minimal & $\begin{array}{l}\text { More (due to } \\
\text { subcutaneous } \\
\text { or intramuscular } \\
\text { accumulation) }\end{array}$ \\
\hline
\end{tabular}

Abbreviations: AVF, arteriovenous fistula; AVM, arteriovenous malformation; EVOH, ethylene vinyl alcohol copolymer; n-BCA, n-butyl cyanoacrylate.

arteriolovenulous nidus structure with absence and presence of dilatation of vascular channels, respectively. Although Type IIIa can be treated only with a transarterial approach, type IIIb can be embolized using either transarterial, transvenous, or direct percutaneous approaches. ${ }^{7}$ - Fig. 3 illustrates the endovascular management employed, based on the AVM nidus type (Cho-Do classification system).

Arterial treatments of AVMs may be undertaken either with the aim of achieving complete obliteration through transarterial route or as a supplementary treatment. ${ }^{34-36}$ The standalone arterial approach (-Fig. 4) and combined (-Figs. 5 and 6 ) arterial and percutaneous approach are commonly undertaken strategies in PAVM management.

The arterial approach as an adjunctive in PAVM treatment involves initial deployment of balloons, coils, plugs, or liquid embolizing agents in the feeding arteries, thus inducing local

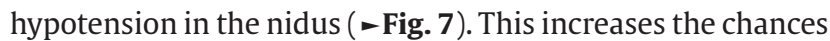
of complete obliteration of the AVM following direct cutaneous or transvenous retrograde AVM embolization (TRAE) approaches subsequently. ${ }^{34-36}$ The reduction of nidal flow achieved by initial adjunctive arterial approach helps achieve 
Table 4 Cho-Do classification system with influence on mode of endovascular management.

\begin{tabular}{|c|c|c|c|}
\hline AVM nomenclature & Nidus type & Morphological description & $\begin{array}{l}\text { Preferred endovascular } \\
\text { management approach }\end{array}$ \\
\hline Arteriovenous & 1 & $\begin{array}{l}\leq 3 \text { feeding arteries, single } \\
\text { outflow vein }\end{array}$ & Transarterial or transvenous \\
\hline Arteriolovenous & II & $\begin{array}{l}\text { > } 3 \text { feeding arteries, single } \\
\text { dominant outflow vein }\end{array}$ & Transvenous \\
\hline Arteriolovenulous & IIla & $\begin{array}{l}\text { Multiple feeding arteries, multi- } \\
\text { ple outflow veins }\end{array}$ & Transarterial \\
\hline Dilated arteriolovenulous & $\begin{array}{l}\text { IIIb (IIla + dilated } \\
\text { vessels) }\end{array}$ & $\begin{array}{l}\text { Dilated multiple feeding arter- } \\
\text { ies, dilated multiple outflow } \\
\text { veins }\end{array}$ & $\begin{array}{l}\text { Transarterial, transvenous or } \\
\text { percutaneous }\end{array}$ \\
\hline
\end{tabular}
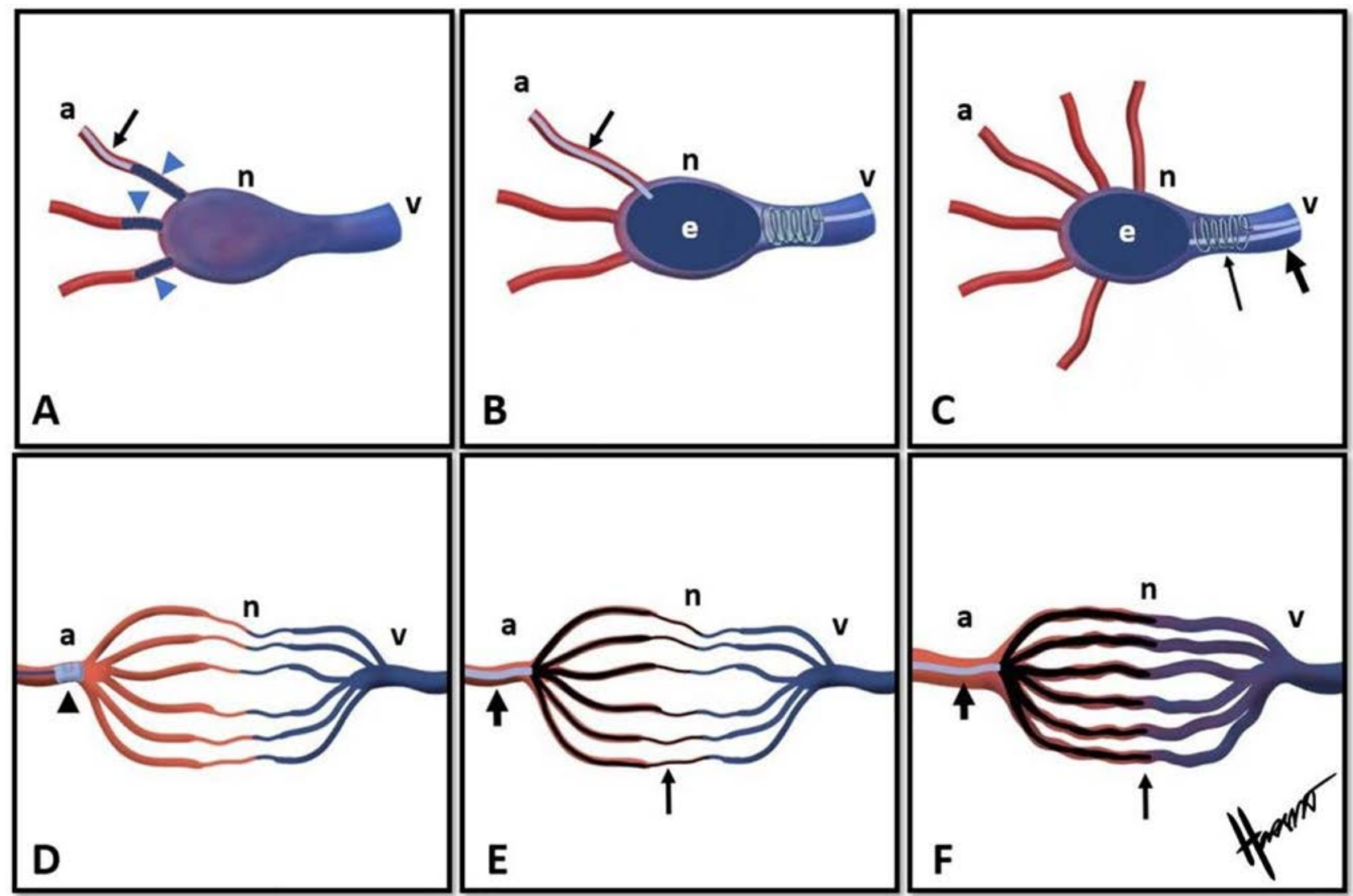

Fig. 3 (A-F) Treatment options for peripheral arteriovenous malformation (PAVM), according to Cho-Do et al classification (A) shows direct embolization of the feeding artery in a type 1 AVM using a microcatheter (arrow) with formation of a cast of liquid embolizing agent within the feeding artery (arrow heads) and the nidus. (B) Venous drainage occlusion using coils, followed by transarterial administration of liquid embolizing agent using a microcatheter (arrow) for a type 1 AVM. (C) Transvenous coil embolization to reduce outflow (thick arrow) followed by transvenous embolization of the nidus through an additional microcatheter (thin arrow) navigated close to the nidus for a type II AVM. (D and E) Transarterial embolization of a type IIla AVM using liquid embolic agent (arrowhead). F: Transarterial embolization of type IIIb AVM using a liquid embolic agent (thin arrow). a: arterial feeder; v: draining vein; nidus (n).

complete obliteration subsequently, not only by permitting longer dwell time of the administered embolic agents (through direct cutaneous or transvenous approaches), but also by minimizing risk of inadvertent embolization to the normal venous circulation. ${ }^{37-40} \mathrm{Lv}$ et al achieved 93.3\% obliteration rates of AVMs using TRAE technique, when supplemented with transarterial embolization initially, underscoring the importance of this dual approach. ${ }^{40}$ However, caution must be exercised with these approaches, as there is real risk of inability to access the nidus subsequently through the previously coiled feeding artery (if the need arises, as in failed transvenous or percutaneous approach) with risk of additional recruitment of arteries and worsening of AVM. ${ }^{39}$

The favorable and unfavorable angioarchitecture for transarterial approach is summarized in - Table $\mathbf{5}$.

Transvenous coil embolization is a preferred technique in cases with a demonstrable dominant outflow vein (DOV), as in Cho do Type 2 AVM (-Fig. 3). The transvenous coil 


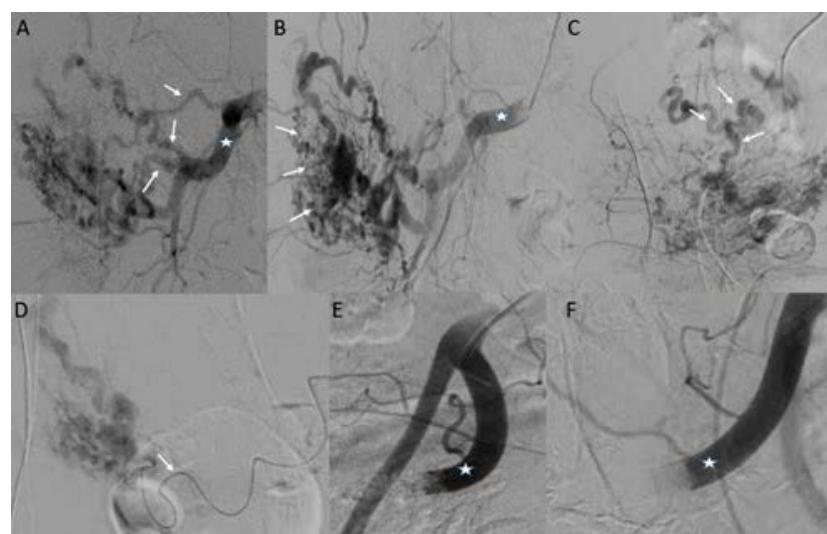

Fig. 4 (A-F) Transarterial embolization in 26-year-old female with Type 1 arteriovenous malformation (AVM) (Cho-Do et al classification). Angiogram shows feeding arteries (arrows in $\mathbf{A}$ ) arising from the posterior trunk of right internal iliac artery (star in $\mathbf{A}$ ), nidal network (arrows in B) and early draining vein (arrow in C). (D) Microcatheter navigated selectively into feeding arteries and 30\% glue (n-butyl cyanoacrylate $[\mathrm{n}-\mathrm{BCA}]$ ) injected. (E, F) Postembolization angiogram shows complete obliteration of nidus and draining vein.

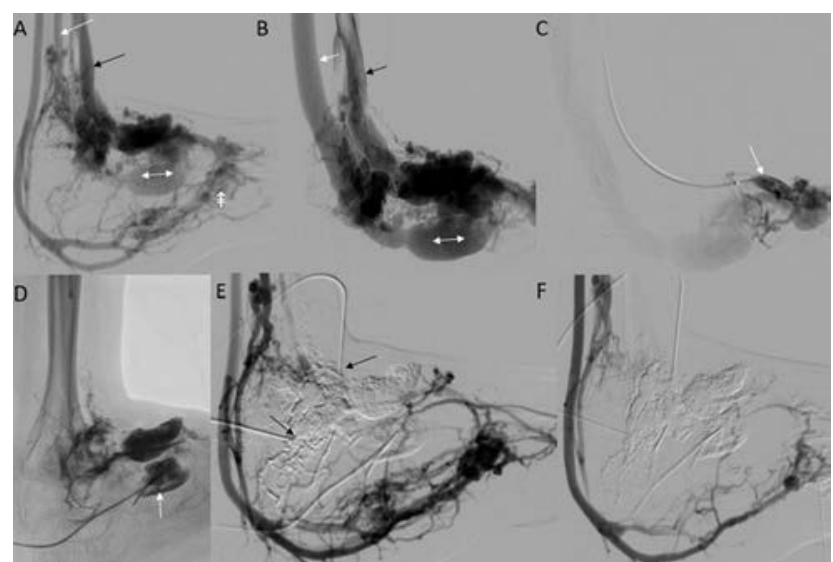

Fig. 5 (A-F) Combined embolization strategy (transarterial and percutaneous) employed in 23-year-old male with a Type 1 right foot arteriovenous malformation (AVM) (Cho-Do et al classification). Enlarged feeding arteries (black arrow in $\mathbf{A}$ and $\mathbf{B}$ ), nidal network (upward arrow with double stroke symbol in $\mathbf{A}$ ), prominent venous sacs (left-right arrows in $\mathbf{A}$ and $\mathbf{B}$ ) and the draining veins (white arrows in $\mathbf{A}$ and $\mathbf{B}$ ) are demonstrated on angiogram. Transarterial glue (n-butyl cyanoacrylate [n-BCA]) administration using microcatheter (white arrow in C) and percutaneous glue injection using multiple scalp needles (arrow in $\mathbf{D}$ and $\mathbf{E}$ ) following reduction of flow consequent to initial transarterial embolizing agent injection. (F) Check angiogram shows complete obliteration of AVM.

placement allows stabilization of the thrombus in the DOV, with concurrent administration of liquid embolic agent into the nidus and adjacent part of vein through either a direct percutaneous approach or catheter parked close to the nidus through a transvenous approach. The low pressure "sump" which is considered to be a very strong stimulus to development of collateral arterial channels is effectively eliminated using transvenous approach and hence provides best opportunity for long-term cure.

The destruction of the nidus endothelium with consequent inability of release of angiogenic factors prevents

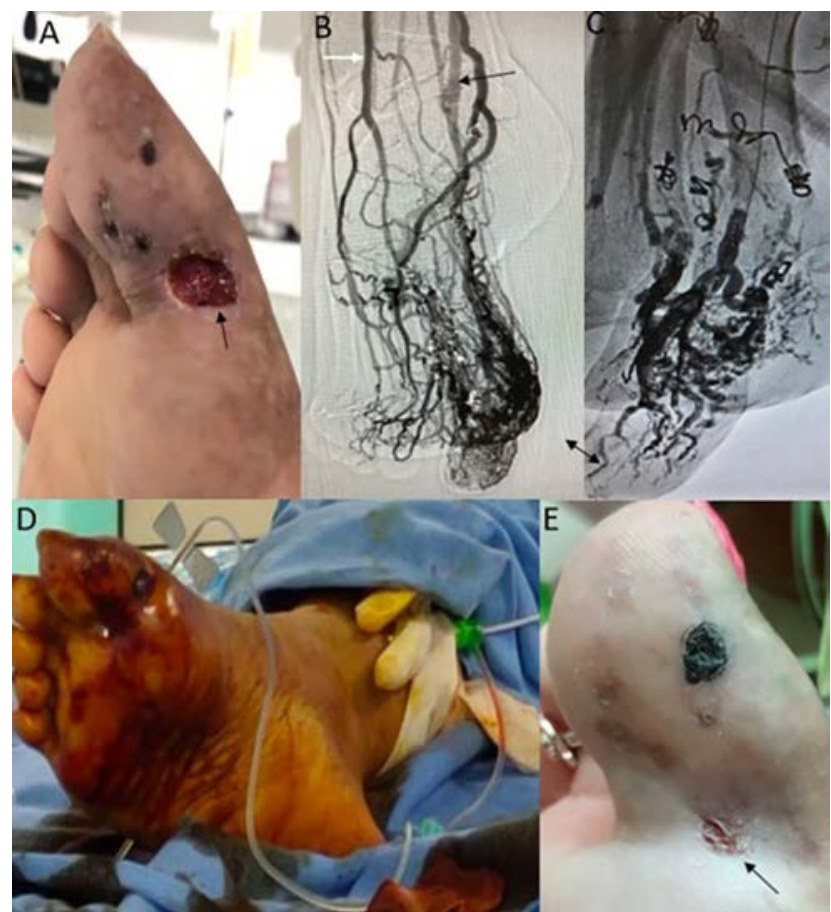

Fig. 6 (A-E) Combined embolization strategy (transarterial and percutaneous) employed in 28-year-old female with a right foot arteriovenous malformation (AVM). A nonhealing ulcer is noted involving the medial aspect of the base of great toe (black arrow in $\mathbf{A}$ ). Feeding arteries (white arrow in $\mathbf{B}$ ), prominent nidus and early draining veins (black arrows in B) are demonstrated on angiogram. Patient was managed with transarterial coiling (C) and percutaneous glue administration using needles (D). Follow-up examination shows complete healing of the great toe ulcer (black arrow in $\mathbf{E}$ ).

Table 5 Transarterial approach: favorable and unfavorable angioarchitecture

\begin{tabular}{|l|l|}
\hline $\begin{array}{l}\text { Preferred situations for } \\
\text { transarterial approach }\end{array}$ & $\begin{array}{l}\text { Challenging situations for } \\
\text { transarterial approach }\end{array}$ \\
\hline Cho-Do Type IIla AVMs & $\begin{array}{l}\text { Cho-Do Type II AVMs (small } \\
\text { and multiple feeding arteries) }\end{array}$ \\
\hline $\begin{array}{l}\text { Minimally tortuous feeding } \\
\text { arteries }\end{array}$ & $\begin{array}{l}\text { Very tortuous feeding arteries } \\
\text { (difficult catheter navigation } \\
\text { to nidus) }\end{array}$ \\
\hline $\begin{array}{l}\text { Cho-Do Type I AVM: } \\
\text { Transarterial or transvenous } \\
\text { Cho-Do Type IIIb AVM: } \\
\text { transarterial, transvenous or } \\
\text { percutaneous }\end{array}$ & $\begin{array}{l}\text { Nidus very close to normal } \\
\text { branching arteries (Inadvertent } \\
\text { embolization of normal } \\
\text { branching arteries) }\end{array}$ \\
\hline
\end{tabular}

Abbreviation: AVM, arteriovenous malformation.

vessel recruitment and recurrence of AVM following ethanol sclerotherapy. ${ }^{18}$ The intense sclerosing effect of the ethanol can be utilized to much benefit in the treatment of an AVM, provided the agent remains localized to the nidus. This can be achieved with flow reduction techniques using coils, plugs, or balloons. ${ }^{37}$ Jackson et $\mathrm{al}^{38}{ }^{38} \mathrm{Cho}$ et $\mathrm{al}^{28}$ and Linden et $\mathrm{al}^{39}$ demonstrated successful treatment of PAVMs through a transvenous approach using ethanol in conjunction with coil embolization. Yakes classified PAVMs into six types (Ia, IIa, IIb, IIIa, IIIb and IV) based on nidus angioarchitecture, which is limited to ethanol use as the sole embolizing agent 


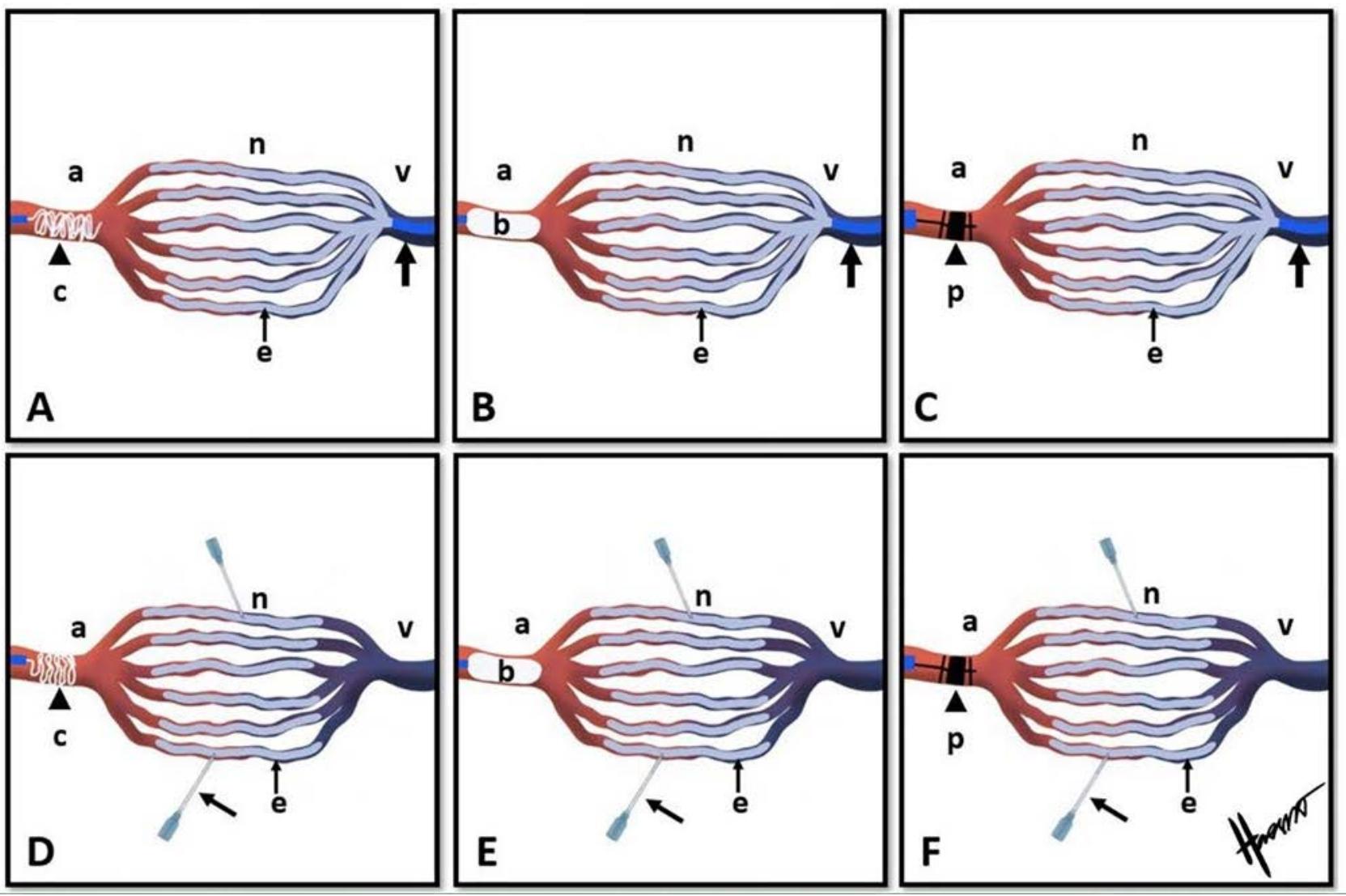

Fig. 7 (A-F) Strategies to induce localized hypotension within the nidus of an arteriovenous malformation (AVM) through transarterial route. $(\mathbf{A}, \mathbf{B}, \mathbf{C})$ : Transarterial coil ( $\mathrm{c}$ in $\mathbf{A}$ ), balloon ( $\mathrm{B}$ in $\mathbf{B}$ ) and plug ( $\mathrm{p}$ in $\mathbf{C}$ ) occlusion followed by transvenous embolization of nidus (e) using liquid embolization agent. (D, E, F): Transarterial coil ( $\mathrm{c}$ in $\mathbf{A})$, balloon ( $\mathrm{b}$ in $\mathbf{B}$ ) and plug ( $\mathrm{p}$ in $\mathbf{C}$ ) occlusion followed by direct percutaneous embolization of the nidus using liquid embolization agent (e). A: arterial feeder; $v$ : draining vein; $n=$ nidus.

or in conjunction with mechanical occlusion (coils, or plugs), depending on the nidus type. ${ }^{8}$ Risks associated with embolization, including surrounding tissue ischemia, nontarget embolization, intra or postprocedural vascular rupture and incomplete embolization of the AVM, warrant assessment of individualized benefit risk ratio and case-based treatment strategy. The sudden hemodynamic changes encountered following complete AVM embolization in one sitting is the likely explanation of post embolization rupture and bleed. ${ }^{40}$ Inadvertent nontargeted downstream embolization of peripheral, pulmonary, coronary, and cerebral circulation can lead to limb ischemia, pulmonary embolism (PE), acute coronary syndrome (ACS) and stroke, respectively. ${ }^{41}$ Recanalization consequent to recruitment of additional vessels following incompletely embolized AVM is not uncommon. ${ }^{42}$ Also, there is risk of coil embolization failure consequent to coagulopathies or anticoagulation therapy. Intense pain, need of general anesthesia, potential for intense skin necrosis, PE, and arterial hypertension are some of the important drawbacks with ethanol sclerosing agent. ${ }^{18,43}$ The obliteration of the nidus is important to achieving complete cure and minimizing recurrence risk in patients with PAVM. Failure to navigate catheter to the nidus (consequent to unfavorable angioarchitecture) merits consideration of surgery to achieve higher cure rates. ${ }^{44}$ Outcomes following standalone endovascular treatment vary considerably with small PAVM (with a single draining vein) demonstrating high cure rates, whereas large, diffuse AVMs documenting suboptimal results, necessitating multimodality management (including surgical intervention) ${ }^{45}$ The best clinical outcome can be achieved if management is undertaken by a multidisciplinary team comprising interventional radiologists, plastic/vascular surgeon and dermatologist. Lower recurrence rates are documented if aggressive embolization is combined with surgical resection in appropriately selected cases. ${ }^{46}$ Although the classical Schobinger stage I lesion is clinically quiescent and is usually managed with observation and close follow-up, the extensive diffuse stage I lesions show better outcome with application of compressive stockings. ${ }^{47}$

\section{Conclusion}

The peripheral HFVMs show varied clinical presentation and frequently pose a diagnostic and therapeutic challenge. While the ISSVA classification system is the most commonly accepted system for classifying congenital vascular anomalies in clinical practice, the Cho-Do et al classification is of utmost help in guiding optimal treatment in PAVMs. Although transarterial approach remains the most commonly employed route for PAVM embolization, the role of 
transvenous and direct percutaneous approach is increasing. The endovascular approach undertaken depends on angioarchitecture of the AVM.

\section{Conflict of Interest}

None declared.

\section{Acknowledgment}

- Figs. 1, 3 and 7 have been drawn in original by Dr. Harshith Kramadhari (one of the authors of this article).

\section{References}

1 Mulliken JB, Fishman SJ, Burrows PE. Vascular anomalies. Curr Probl Surg 2000;37(8):517-584

2 Hand JL, Frieden IJ. Vascular birthmarks of infancy: resolving nosologic confusion. Am J Med Genet 2002;108(4):257-264

3 Mulliken JB, Glowacki J. Hemangiomas and vascular malformations in infants and children: a classification based on endothelial characteristics. Plast Reconstr Surg 1982;69(3):412-422

4 Jackson IT, Carreño R, Potparic Z, Hussain K. Hemangiomas, vascular malformations, and lymphovenous malformations: classification and methods of treatment. Plast Reconstr Surg 1993;91(7):1216-1230

5 Enjolras O. Classification and management of the various superficial vascular anomalies: hemangiomas and vascular malformations. J Dermatol 1997;24(11):701-710

6 Wassef M, Blei F, Adams D, et al. ISSVA Board and Scientific Committee. Vascular anomalies classification: recommendations from the International Society for the Study of Vascular Anomalies. Pediatrics 2015;136(1):e203-e214

7 Cho SK, Do YS, Shin SW, et al. Arteriovenous malformations of the body and extremities: analysis of therapeutic outcomes and approaches according to a modified angiographic classification. J Endovasc Ther 2006;13(4):527-538

8 Yakes WF. Yakes' AVM classification system. J Vasc Interv Radiol 2015;26:S224

9 Dubois J, Garel L. Imaging and therapeutic approach of hemangiomas and vascular malformations in the pediatric age group. Pediatr Radiol 1999;29(12):879-893

10 Donnelly LF, Adams DM, Bisset GS II. Vascular malformations and hemangiomas: a practical approach in a multidisciplinary clinic. AJR Am J Roentgenol 2000;174(3):597-608

11 Fayad LM, Hazirolan T, Bluemke D, Mitchell S. Vascular malformations in the extremities: emphasis on MR imaging features that guide treatment options. Skeletal Radiol 2006;35(3):127-137

12 Ernemann U, Kramer U, Miller S, et al. Current concepts in the classification, diagnosis and treatment of vascular anomalies. Eur J Radiol 2010;75(1):2-11

13 Dobson MJ, Hartley RW, Ashleigh R, Watson Y, Hawnaur JM. MR angiography and MR imaging of symptomatic vascular malformations. Clin Radiol 1997;52(8):595-602

14 Kohout MP, Hansen M, Pribaz JJ, Mulliken JB. Arteriovenous malformations of the head and neck: natural history and management. Plast Reconstr Surg 1998;102(3):643-654

15 Saran S, Malik S, Sharma Y, Kharbanda A. High-flow type of peripheral arteriovenous malformation causing severe cosmetic deformity. Ann Afr Med 2019;18(2):117-119

16 Legiehn GM, Heran MK. A step-by-step practical approach to imaging diagnosis and interventional radiologic therapy in vascular malformations. Semin Intervent Radiol 2010; 27(2):209-231
17 Paltiel HJ, Burrows PE, Kozakewich HP, Zurakowski D, Mulliken JB. Soft-tissue vascular anomalies: utility of US for diagnosis. Radiology 2000;214(3):747-754

18 Yakes WF. Endovascular management of high-flow arteriovenous malformations. Semin Intervent Radiol 2004;21(1): 49-58

19 Moukaddam H, Pollak J, Haims AH. MRI characteristics and classification of peripheral vascular malformations and tumors. Skeletal Radiol 2009;38(6):535-547

20 Hyodoh H, Hori M, Akiba H, Tamakawa M, Hyodoh K, Hareyama M. Peripheral vascular malformations: imaging, treatment approaches, and therapeutic issues. Radiographics 2005;25 (1 Suppl 1):S159-S171

21 Dubois J, Alison M. Vascular anomalies: what a radiologist needs to know. Pediatr Radiol 2010;40(6):895-905

22 Navarro OM, Laffan EE, Ngan BY. Pediatric soft-tissue tumors and pseudo-tumors: MR imaging features with pathologic correlation: part 1. Imaging approach, pseudotumors, vascular lesions, and adipocytic tumors. Radiographics 2009;29(3):887-906

23 Dunham GM, Ingraham CR, MakiJH,VaidyaSS. Finding the nidus: detection and workup of non-central nervous system arteriovenous malformations. Radiographics 2016;36(3):891-903

24 Kawanabe $\mathrm{T}$, Wakita $\mathrm{S}$, Harii $\mathrm{K}$, Hayashi $\mathrm{N}$, Inoue $\mathrm{Y}$. Sclerotherapy of hemangiomas and vas-cular malformations in lips. Jpn J Plast Reconstr Surg 1996;16:852-862

25 Herborn CU, Goyen M, Lauenstein TC, Debatin JF, Ruehm SG, Kröger K. Comprehensive time-resolved MRI of peripheral vascular malformations. AJR Am J Roentgenol 2003;181(3):729-735

26 Ohgiya Y, Hashimoto T, Gokan T, et al. Dynamic MRI for distinguishing high-flow from low-flow peripheral vascular malformations. AJR Am J Roentgenol 2005;185(5):1131-1137

27 Liu AS, Mulliken JB, Zurakowski D, Fishman SJ, Greene AK. Extracranial arteriovenous malformations: natural progression and recurrence after treatment. Plast Reconstr Surg 2010;125(4):1185-1194

28 Cho SK, Do YS, Kim DI, et al. Peripheral arteriovenous malformations with a dominant outflow vein: results of ethanol embolization. Korean J Radiol 2008;9(3):258-267

29 Strauss I, Haim O, Umansky D, et al. Impact of onyx embolization on radiosurgical management of cerebral arteriovenous malformations: treatment and outcome. World Neurosurg 2017;108:656-661

30 Ayad M, Eskioglu E, Mericle RA. Onyx: a unique neuroembolic agent. Expert Rev Med Devices 2006;3(6):705-715

31 Vaidya S, Tozer KR, Chen J. An overview of embolic agents. Semin Intervent Radiol 2008;25(3):204-215

32 Do YS, Yakes WF, Shin SW, et al. Ethanol embolization of arteriovenous malformations: interim results. Radiology 2005;235(2):674-682

33 Pimpalwar S. Vascular malformations: approach by an interventional radiologist. Semin Plast Surg 2014;28(2):91-103

34 Lv X, Song C, He H, Jiang C, Li Y. Transvenous retrograde AVM embolization: Indications, techniques, complications and outcomes. Interv Neuroradiol 2017;23(5):504-509

35 Barral PA, Saeed-Kilani M, Tradi F, et al. Transcatheter arterial embolization with ethylene vinyl alcohol copolymer (Onyx) for the treatment of hemorrhage due to uterine arteriovenous malformations. Diagn Interv Imaging 2017;98(5):415-421

$36 \mathrm{Kim} \mathrm{SH}$, Kim TG, Kong MH. Transarterial balloon-assisted onyx embolization of intracranial arteriovenous malformations using a dual-lumen balloon microcatheter: two case reports. J Cerebrovasc Endovasc Neurosurg 2017;19(3):223-230

37 Lee BB. New approaches to the treatment of congenital vascular malformations (CVMs)-a single centre experience. Eur J Vasc Endovasc Surg 2005;30(2):184-197 
38 Jackson JE, Mansfield AO, Allison DJ. Treatment of high-flow vascular malformations by venous embolization aided by flow occlusion techniques. Cardiovasc Intervent Radiol 1996;19(5):323-328

39 van der Linden E, van Baalen JM, Pattynama PM. Retrograde transvenous ethanol embolization of high-flow peripheral arteriovenous malformations. Cardiovasc Intervent Radiol 2012;35(4):820-825

40 Pines A, Aoun RJ, Halasa TK, Sattur M, Zammar SG, Bendok BR. Toward individualized neurosurgery: quantifying arteriovenous malformation embolization with magnetic resonance angiography. World Neurosurg 2015;84(5):1184-1185

41 Oklu R. Thrombosis. Cardiovasc Diagn Ther 2017;7(3):131-133

42 Wicky S, Pinto EG, Oklu R. Catheter-directed thrombolysis of arterial thrombosis. Semin Thromb Hemost 2013;39(4):441-445

43 Naidu SG, Knuttinen MG, Kriegshauser JS, Eversman WG, Oklu R. Rationale for catheter directed therapy in pulmonary embolism. Cardiovasc Diagn Ther 2017;7(3,Suppl 3) :S320-S328
44 Park KB, Do YS, Kim DI, et al. Predictive factors for response of peripheral arteriovenous malformations to embolization therapy: analysis of clinical data and imaging findings. J Vasc Interv Radiol 2012;23(11):1478-1486

45 Lee BB, Baumgartner I, Berlien HP, et al. International Union of Angiology. Consensus Document of the International Union of Angiology (IUA)-2013. Current concept on the management of arterio-venous management. Int Angiol 2013;32(1):9-36

46 Goldenberg DC, Hiraki PY, Caldas JG, Puglia P, Marques TM, Gemperli R. Surgical treatment of extracranial arteriovenous malformations after multiple embolizations: outcomes in a series of 31 patients. Plast Reconstr Surg 2015;135(2):543-552

47 Upton J, Coombs CJ, Mulliken JB, Burrows PE, Pap S. Vascular malformations of the upper limb: a review of 270 patients. J Hand Surg Am 1999;24(5):1019-1035 